\title{
Renovation of residential areas for benefit of builders, state and citizens
}

\author{
Olga Grushina $^{1}$, Irina Torgashina ${ }^{1}$ \\ ${ }^{12}$ Baikal State University, 664003, Lenina, 11 st., Irkutsk, Russia,
}

\begin{abstract}
The paper deals with the problem of residential housing renovation projects for benefit of builders, citizens and state. The numerous interpretations of the "renovation" term we understand here as a complete renovation of the housing stock, i.e. demolition of old buildings and construction of new ones in contrast to their reconstruction and modernization. In other words, the renovation is considered as an urgent city-planning challenge involving changes in the field of territorial planning. On the example of the classic "Khrushchev" quarter of Irkutsk city, the authors propose a pilot renovation project with the distribution of roles and expenditures of all participants. The analysis conducted allows drawing a conclusion that renovation will be beneficial to the builder only if budget funds are invested in these projects in order to compensate the costs related to temporary resettlement of citizens from demolished dwellings. Another prerequisite is the governmental repurchase of apartments intended for resettlement of citizens from demolished housing at the prices not lower than those set by the authorities in the region. Citizens are ready to support renovation projects in case of their returning to their former place of residence in conditions improved from the point of view of the living environment comfort. To ensure the profit of the builder, the living area of the newly commissioned housing should exceed the area of the demolished housing by no less than one and a half times, provided that cheap technologies of modern prefabricated housing are used.
\end{abstract}

\section{Introduction}

In 2018, the construction industry of the Russian Federation is shaken by the changes (developed at the legislative level) related to substitution of shared financing of housing construction by the project one. The main argument here is the problem of fighting against fraud and protecting the rights of coinvestors: allegedly "changing the conditions of construction by refusing to participate in sharing can alter the surrounding reality and play an important role in preventing mercenary crime in the designated area” [1, p. 98]. Construction, being quite problematic branch, which, despite all the predictions, did not become the engine for the development of our economy, is on the verge of increasing further difficulties in terms of reducing financing opportunities, a shortage of working capital, as a consequence, the bankruptcy of small enterprises, increased monopolization, and eventually, an increase in prices on final products.

According to some expert estimation [2, p. 339], almost a quarter of the population of the Russian Federation is not able to solve their housing problems without state assistance: "The problem of housing affordability is caused by the low income of a significant part of the population and underdeveloped mechanisms of effective state participation in the city-planning process. Record volumes of housing commissioning in the 80s (in 1987, 76.4 million square meters of living space was built) are due to the high share of state capital investments in housing construction (more than 85\%)." 
And the percentage of families that are able to purchase housing using own and borrowed funds, which grew from 2004 to 2008 from 9 to $17.8 \%$, increased only to $24.7 \%$ over the next 7 years [3, p. 38]. At the same time, $41 \%$ of Russian families are not satisfied with their housing and living conditions [4, p. 43]. State programs in the field of housing affordability have evolved from the first the State Target Program "Housing" through several stages of the Federal Program "Housing" to the state program "Providing affordable and comfortable housing and public services to citizens of the Russian Federation" for 2018-2025. The principal main targets remain the same: the annual volume of housing commissioning, including standard and low-prize; the level of housing provision; the number of families of all categories of citizens who improved their living conditions within the framework of the Program's activities; reduction of the share of dilapidated and emergency housing stock in the total area of the housing stock of the country and regions, the level of housing affordability for the population [2, p. 342].

It should be admitted that programs aimed at resettlement of citizens from dilapidated and emergency housing gave a good opportunity for all categories of population to take advantage of state support to improve their living conditions and provide construction organizations, including small ones in all regions of the country, with spread of activities. The logical extension of such programs, in our opinion, should be the renovation of not only emergency, but also obsolete housing stock, which is close to be recognized as unsuitable both for physical grounds and especially moral reasons. Renovation is another slogan, a loud program with the next stage of completion in 2018, which became known all over the country on the example of the renovation of residential buildings in Moscow.

\section{Methods and experience of project management of residential buildings renovation}

Renovation of the existing residential areas is among urgent city-planning challenges affecting changes in the field of territorial planning. Such changes should include: improvement of the living conditions of citizens: enhancement of safety and comfort; improvement of social and economic parameters of the urban housing stock; effective use of urban areas; renovation of city infrastructure; urban development; improvement of transport and environmental conditions in the city; improvement of social and economic spheres of life of citizens; improvement of the moral and aesthetic appearance of the city [5, p. 77-78].

Following the works of I.L. Kievsky, one can agree that "from the point of view of organization, renovation in the quarters of the existing development represents a "wave" process: starting houses are first built, then residents of demolished houses are relocated, old buildings are demolished and new ones are constructed out on the vacated sites. At the same time, a part of the apartments in new houses is used for resettlement, and the rest one with time is sold on the market” [6, p. 4].

Experts of the World Bank ${ }^{1}$ have identified four key stages in the framework of renovation projects: the scope, planning, financing and implementation.

The main objects of renovation are the land, urban environment and population; the main methods for managing the renovation processes become the program-target and project ones. The developed general program of the renovation of a city or region is specified through separate investment and construction projects that determine the scope of work with access to specific physical objects of construction (buildings, etc.) [7, p. 158; 4, p. 43]. 
Also, according to A.N. Kirillova, in the implementation of housing renovation programs, it is necessary to apply the methods of project management through a project-oriented management system²; methods of territorial development, business planning, portfolio management [8, p. 18-20].

Although a vector of state policy in the investment sphere, to a large extent, is focused on decentralization of investments [9, p. 110], the renovation program is primarily aimed at improving the living conditions of citizens. Mainly this is a social project. This is why it is mandatorily implemented using budget funds. At the same time, part of the housing that is not involved in the "wave" resettlement will be sold, which will make commercial developers interested. Another key principle of renovation is to uncover the potential of territories. In the process of renovating the urban environment, an integrated approach should be used to preserve the history of the place and the identity of the city [6, p. 4; 10, p. 236].

When it was decided to start the construction of panel buildings of average height (4-5 floors), this did not require complex technological solutions and significantly reduced construction time. Note that a priority was given to the speed of construction and the simplicity of architectural solutions, while the requirements to the quality of housing, especially with regard to service areas, went by the wayside. The idea of such construction, including the quarter planning of such buildings, goes back to the ideas reflected in the works of French architect of Swiss origin Le Corbusier. "Stalin" houses were more comfortable and larger, but preference was given to the "Khrushchev" houses of French-Swiss origin.

It should be underlined that in the 50-60 of the twentieth century, the share of built middle-rise panel houses in Western Europe reached $50-70 \%$ of all residential buildings [11, p. 81]. Now it is the time to reap the benefits of the choice made half a century ago. Renovation is one of the methods for overcoming Khrushchev's simplicity in favor of the modern quality and comfort of housing in particular, and of the urban environment as a whole.

To calculate the pilot renovation project, we have chosen a land piece with a total area of 43,352.58 $\mathrm{m}^{2}$, which is located in the Oktyabrsky district of Irkutsk city. The amount of living space in the houses of the 335 series is $22,858.76 \mathrm{~m}^{2}$. Per one inhabitant of this microdistrict:

\section{$22,858.76 \mathrm{~m}^{2} / 1,590$ people $=14.38 \mathrm{~m}^{2}$ of living space}

This figure is by $3.62 \mathrm{~m}^{2}$ lower than the social norm of the housing are in Irkutsk $\left(18 \mathrm{~m}^{2}\right.$ per person). Thus, to meet the requirement established by federal and regional legislation, for the "quality" resettlement and the return of residents to their former area of residence, it is necessary:

$$
18 \mathrm{~m}^{2} \times 1590 \text { people }=28620 \mathrm{~m}^{2}
$$

For an equivalent construction intended for resettlement of residents of old houses into new ones, $5,761.24 \mathrm{~m}^{2}$ of housing are is required. New construction will be carried out in five stages.

I stage involves the demolition of a house located at Alexander Nevsky str., 46, letter "B", with a total area of 2,745.5 $\mathrm{m}^{2}$, including living area $2548.4 \mathrm{~m}^{2}$. In the vacated section, there will be launched construction of the apartment block house No. 1 with two block sections No. 1 and No. 2 of 9 and 10 floors high and a total area of 6,841.74 $\mathrm{m}^{2}$ including living area of $6146.6 \mathrm{~m}^{2}$. Thus, at the end of the construction of the first stage, the apartment building No. 1 will be able to compensate for the living areas demolished at the beginning of the construction of the first stage $(2,548.40 * 1.252=$ $3,190.6 \mathrm{~m}^{2}$ ) and provide another 2,956 $\mathrm{m}^{2}$ of living space.

II stage of construction includes a rehousing from rented buildings of the residents of a previously demolished house, together with a partial settlement of residents whose houses are demolished at stage II.

At this stage, the houses, located on Trilissera 38 and Alexander Nevsky 46a, are demolished. The total area for demolition is 6,709.5 $\mathrm{m}^{2}$, including the living one of $5,154.5 \mathrm{~m}^{2}$. Thus, rehousing of residents from these buildings requires 5,154.5 $* 1.252=6,453.43 \mathrm{~m}^{2}$. From the first stage, 2,956 $\mathrm{m}^{2}$ are left, hence $3,497.43 \mathrm{~m}^{2}$ are missing. The remaining $\approx 194$ people are temporarily rehoused in rented apartments. 
The second stage involves the construction of an apartment building number 2, which includes two block sections of 9 and 10 floors with a living area of $6,146.6 \mathrm{~m}^{2}$.

Based on the calculation of the area of built houses, at the third stage of construction we can rehouse the remained people in the second stage $\left(3,497.43 \mathrm{~m}^{2}\right.$ of living space), adding the area for rehousing from the third stage.

III stage of construction involves rehousing of residents from the second stage to the area of the constructed block sections (3,497.43 $\left.\mathrm{m}^{2}\right) .2,649.17 \mathrm{~m}^{2}$ is remained.

During the demolition of houses located on Partizanskaya 105, 105a, 107, 107a (total area of $11,191.36 \mathrm{~m}^{2}$, including living area of $10,112.26 \mathrm{~m}^{2}$ ), the developer can rehouse a part of the residents in the block sections number 3 and number 4 , built at the second stage. The required housing are for the rehousing of remained people is $10,112.26 * 1,252 \mathrm{~m}^{2}-2,649.17 \mathrm{~m}^{2}=10,013.38 \mathrm{~m}^{2}$ ( $\approx 556$ people per rental area).

It is scheduled a construction of an apartment building number 3 with four block sections of 9, 10 and 11 floors. The total built-up area is 14,405.2 $\mathrm{m}^{2}$ including the living area of 12,942.16 $\mathrm{m}^{2}$.

The residents from the third stage are rehoused on area of 10,011.38 $\mathrm{m}^{2}$. The remaining 2930.78 $\mathrm{m}^{2} \mathrm{~s}$ of living space are intended for rehousing of residents at the fourth stage.

The fourth stage of construction implies the rehousing of residents of the third and fourth stages to the apartment building №4. After demolishing houses from Partizanskaya 109 and 109a, the area for settlement is $5,043.6 * 1.252=6,314.59 \mathrm{~m}^{2}$. These people are partially rehoused $\left(2,930.78 \mathrm{~m}^{2}\right)$ in the block-section No. 8 of the III stage. At the same time, the area for the remaining rehousing is 3,383.81 $\mathrm{m}^{2}$ and the area for sale at the market price is 9,882.83 $\mathrm{m}^{2}$ (apartment building №4 with four block sections No. 9,10,11,12 of 9, 10 and 11 floors).

Stage V involves the sale of the apartments of the fourth stage and on-site improvement.

Based on all of the above, one can calculate the total costs, which are presented in table 1.

Table 1. Total costs of the project, thousand rubles

\begin{tabular}{ccccccc}
\hline \multirow{2}{*}{ Costs } & \multicolumn{7}{c}{ Cost of stages } \\
\cline { 2 - 7 } & 0 stage & 1 stage & 2 stage & 3 stage & 4 stage & 5 stage \\
\hline Rehousing & - & 172027 & 21370 & 61172 & 20676 & - \\
Demolition & - & 1956 & 3912 & 7825 & 7825 & - \\
Building & - & 170135 & 170135 & 358179 & 367133 & - \\
$\begin{array}{c}\text { Facing the façade } \\
\text { On-site }\end{array}$ & - & - & - & - & - & 3463 \\
$\begin{array}{c}\text { improvement } \\
\text { Management }\end{array}$ & - & - & - & - & - & 9400 \\
TOTAL & 1560 & 1950 & 2145 & 2145 & 2600 & 1560 \\
TOTAL OF THE & 1560 & 191243 & 197562 & 4293199 & 398234 & 14423 \\
PROJECT & & & & & &
\end{tabular}

The developer's revenue consists of two parts. The first part is the sale of square meters of the total area to the state at an average market value of 37,914 rubles per $\mathrm{m}^{2}$ according to the Order of the Ministry of Construction and Housing and Communal Services of the Russian Federation of April 27, 2018 since it is a program of rehousing from dilapidated housing. The second part of the revenue is the sale of the remaining square meters of housing at an average market price of 58,000 rubles per $\mathrm{m}^{2}$.

\section{The residential area renovation: income statement}


Based on the income statement, it can be concluded that this project is beneficial for the investordeveloper since a profit is 552,858,076.78 rubles. Despite the fact that at the 0 and I stages the developer will have a loss, the net profit begins to increase at the second stage. This is due to the fact that at the second stage the developer will receive money from state financing for rehousing costs. According to the income statement, the renovation project fully compensates the indexed demolished square meters, while the developer will receive an area for sale in the new housing market. However, negative profits can scare away the investor-developer, therefore, for the continuous implementation of all project activities, avoiding cash gaps and negative net cash flow, a long-term loan of 70,000,000 rubles at $9.5 \%$ per annum is required. The result of the calculation of the financial results of the project is presented in Table 2 .

Table 2. Income statement

\begin{tabular}{|c|c|c|c|c|c|c|}
\hline Indices & 0 stage & I stage & II stage & III stage & IV stage & V stage \\
\hline \multicolumn{7}{|c|}{ Revenues and expenses } \\
\hline 1. Revenue, RUB’ 000 & & 126631 & 309463 & 516181 & 255453 & 638035 \\
\hline $\begin{array}{l}\text { Refund for rehousing, } \\
\text { RUB' } 000\end{array}$ & & 172027 & 21370 & 61172 & 20676 & \\
\hline $\begin{array}{l}\text { 2. Cost of sales, RUB' } \\
000\end{array}$ & 0,00 & 189293 & 195417 & 427175 & 395634 & 12863 \\
\hline $\begin{array}{l}\text { 3. Administrative } \\
\text { expenses, RUB' } 000\end{array}$ & 1560 & 1950 & 2145 & 2145 & 2600 & 1560 \\
\hline $\begin{array}{l}\text { 4. Sales profit, RUB' } \\
000 \\
\text { 5. Loan interests }\end{array}$ & -1560 & -47410 & 133271 & 148033 & -122105 & 623612 \\
\hline $\begin{array}{l}\text { (70 000, 9,5\%), RUB' } \\
000\end{array}$ & 6650 & 6650 & 6650 & 6650 & 6650 & 6650 \\
\hline $\begin{array}{l}\text { 6. Before tax profit } \\
\text { (loss) (accounting } \\
\text { income), RUB' } 000\end{array}$ & -8210 & -54060 & 126621 & 141383 & -128755 & 616962 \\
\hline $\begin{array}{l}\text { 7. Current income tax, } \\
\text { RUB' } 000 \\
\text { 8. Net income (loss) }\end{array}$ & & & 25324 & 28277 & & 123392 \\
\hline $\begin{array}{l}\text { for a period, RUB' } \\
000\end{array}$ & -8210 & -54060 & 101297 & 113106 & -128755 & 493570 \\
\hline $\begin{array}{l}\text { Net profit of renovatio } \\
\text { The loan is used } t \\
\text { fourth stage, the net }\end{array}$ & $\begin{array}{l}\text { p project fo } \\
\text { o cover los } \\
\text { ncome, acc }\end{array}$ & $\begin{array}{l}\text { Il } 5 \text { stages: } \\
\text { s in the net } \\
\text { nulated dur }\end{array}$ & $\begin{array}{r}51 \\
\text { sh flow at } \\
\text { stages II }\end{array}$ & $\begin{array}{l}948 \text { thousa } \\
\text { he } 0 \text { and I } \\
\text { d III, will }\end{array}$ & $\begin{array}{l}\text { rubles } \\
\text { ages of th } \\
\text { enough tc }\end{array}$ & $\begin{array}{l}\text { ject. } \\
\text { npensa }\end{array}$ \\
\hline
\end{tabular}

\section{Discussion and conclusions}

In the works of foreign authors, renovation is associated with modernization and reconstruction and includes the following directions: renovation of obsolete housing stock, improvement of environmental friendliness and energy efficiency of buildings, improvement of the quality of life (social aspect) and housing affordability (economic aspect). To overcome low productivity and conflict of interest, the authors advocate for the development of new forms of cooperation between various partners involved in construction projects [12-14].

Meanwhile, Russian researchers hold the opinion that the renovation program should be applied to such problems that cannot be solved by means of modernization, reconstruction or major repairs. The closest term to renovation is the "redevelopment", which, on the one hand, implies a complete 
cleaning of the territory with the construction of new building, and on the other, any improvement or renovation of urban development [5, p. 73]. However, unlike redevelopment, renovation is impossible without state participation.

In this regard, some authors believe that "the overwhelming majority of Russian cities require the adoption and planned implementation of renovation programs; local authorities should provide finance and physical resources for the reproduction of the housing stock; the state should initiate a national policy on housing renovation" [15, p. 39]. The national policy in terms of the renovation of the regional housing stock will allow intensifying interregional competition for strategic resources, primarily for human capital [16, p. 417]. An important component of interregional competition should be renovation processes aimed at reproducing competitive housing facilities and, ultimately, at reducing the price of consumption (purchase) and operation of these objects for the population [17, p. 20]. Our project experience in renovation has shown that the project may be of interest to the developer in the case of maximizing the area of newly built housing using the most straightforward technologies. "According to the estimations, even a $1 \%$ increase in the cost of an apartment reduces the organization's profit by $10 \%$ and decreases profitability in the construction business" [18, p. 261]. As a result, the developer saves on quality and the "Khrushchev" houses are replaced by more modern, but also prefabricated panel buildings, in which the construction of the 9-storey section, according to the object estimate, will cost 7,517 thousand rubles.

The calculations of a pilot renovation project of the classical Khrushchev quarter, in Irkutsk city permit us to draw the following conclusions. Renovation will be beneficial to the developer only if (i) "long" borrowed money are invested in these projects; (ii) budget funds reimburse the expenses for temporary rehousing of citizens from demolished houses; (iii) the state buy apartments intended for rehousing the people from demolished housing at the prices comparable to those set by the authorities in the region.

\section{References}

[1] A.P. Sukhodolov, N.G. Novikova, T.I. Kubasova, G.V. Khomkalov, I.V. Lavygina. Russian Journal of Criminology. T. 12. № 1, 92-100 (2018)

[2] T.V. Svetnik. Bulletin of Irkutsk National Research Technical University. № 12 (95), 336-342 (2014)

[3] N.B. Kosareva, A.S. Puzanov, T.D. Polidi. Urban research and practice, pilot issue. 33-54 (2015)

[4] T.I. Kubasova. Logistics technologies in modern models of economic development: proceedings / under. ed. V. S. Kolodin. Irkutsk: Publishing house of the BSU, 42-49 (2016)

[5] A.N. Kirillova. Real estate: Economics, management. № 3,. 16-21 (2017)

[6] D.K. Polyakov, S.V. Pupentsova. Fundamental and applied research in management, Economics and trade: proceedings: St. Petersburg: publishing House of the Polytechnic University, 72-79 (2017)

[7] I.L. Kievskiy, A.A. Sergeeva. Naukovedenie. T. 9, № 6, 1-17 (2017)

[8] A.S. Vilkova, D.V. Marennikova. International research journal. № 06 (60), 155-159 (2017)

[9] A.F. Shupletsov, Yu.A. Skorobogatova. Proceedings of Universities. Investment. Construction. Real estate. T. 8, № 1, 109-120 (2018)

[10] A.A. Barabanov. Eco-potential. № 3-4, 237-248 (2013)

[11] G.V. Babenko. Bulletin of Krags. Series "Theory and practice of management". № 18 (23), .81-84 (2017)

[12] Per Anker Jensen, Esmir Maslesa, Christian Thuesen, Jakob Brinkø Berg. Building and Environment. № 143 (2018) 
[13] S. Foroughi, M.A. Rasol. The Egyptian Journal of Remote Sensing and Space Sciences. №19, 323-332 (2016)

[14] F. Barbosa, J. Woetzel, J. Mischke, M. J. Ribeirinho, M.Sridhar, M. Parsons, N. Bertram, S. Brown. Reinventing construction: a route to higher productivity, McKinsey Global Institute, February, p. 44 (2017)

[15] N.Yu. Ulitskaya, T.V. Tolstova, T.G. Ashirova, I.I. Abdrazakova. Economic vector. № 4 (22), 35-42 (2018)

[16] S.A. Korostin. Fundamental Research. №5, 415-418 (2015)

[17] E.V. Nezhnikova. Real estate: Economics, management. №4, 20-24 (2016)

[18] T.V. Svetnik. Euro-Asian cooperation: proceedings: Irkutsk: Publishing house of the BSU, 256-262 (2017) 